\title{
MENGENAL DUNIA KTSP \\ (Optimalisasi Peran KTSP di Lembaga Pendidikan)
}

Oleh : Baharuddin

\author{
Pembantu RektorBidang Kemahasiswaan UIN Malang dan \\ Dosen Tetap Fakultas Tarbiyah UIN Malang
}

\begin{abstract}
Abstrak
Within the context of Indonesian history, it has been known that Indonesia is a country that never consistent to deal with its educational system (i.e. curriculum). This phenomenon can be seen through the changing of curriculum during 1968, 1975, 1984, 2004, and 2006. The last curriculum development (i.e. in 2006) is called as KTSP (kurikulum tingkat satuan pelajaran). The purpose of KTSP is to design curriculum which based on educational autonomy. This curriculum development indicates that the curriculum will train Indonesian human resources to adapt the challenges of social changes.
\end{abstract}

Key Word: KTSP, Kurikulum, Pendidikan, Guru dan Siswa, Sekolah/Madrasah

\section{A. Pendahuluan}

Sejak tahun 2001, berdasarkan Undang-Undang Nomor 22 Tahun 1999 tentang Pemerintahan Daerah, telah diberlakukan otonomi daerah bidang pendidikan dan kebudayaan. Visi pokok dari otonomi dalam penyelenggaraan pendidikan bermuara pada upaya pemberdayaan (empowering) terhadap masyarakat setempat untuk menentukan sendiri jenis dan muatan kurikulum, proses pembelajaran dan sistem penilaian hasil belajar, guru dan kepala sekolah, fasilitas dan sarana belajar untuk putra-putri mereka. Peran pemerintah baik diwakili oleh Departemen Teknis maupun oleh pemerintah daerah (Pemda) di tingkat kecamatan, kabupaten, propinsi adalah memberikan dukungan baik berupa dana, fasilitas, dan ekspertis agar dapat terselengggaranya pelayanan pendidikan yang bermanfaat bagi pembangunan kehidupan riil di masyarakat dan dilakukan oleh masyarakat sendiri dengan mengacu pada standar mutu akademik secara nasional maupun internasional.

Dilihat dari visi tersebut, maka kata kunci dari otonomi daerah adalah "kewenangan" dan "pemberdayaan". Otonomi daerah di bidang pendidikan berusaha memberikan kembali pendidikan kepada masyarakat pemiliknya (daerah) agar hidup dari, oleh dan untuk masyarakat di daerah tersebut, atau berusaha memandirikan suatu lembaga atau suatu daerah untuk mengurus dirinya sendiri melalui pemberdayaan SDM yang ada di 
daerahnya. Sebagai konsekuensinya, maka sebagian besar sumber pembiayaan nasional dilimpahkan lebih banyak ke daerah sesuai dengan potensi dan kemampuan perekonomian daerah yang berbeda-beda.

Otonomi penyelenggaraan pendidikan tersebut pada gilirannya berimplikasi kepada perubahan sistem manajemen pendidikan dari pola sentralisasi ke desentralisasi dalam pengelolaan pendidikan. Sebagai implikasi selanjutnya ialah dikembangkannya pendidikan yang demokratis dan non-monopolistik dalam menentukan jenis dan muatan kurikulum, proses pembelajaran dan sistem penilaian hasil belajar, fasilitas dan sarana belajar dan lain-lain. Bersamaan dengan otonomi penyelenggaraan pendidikan tersebut, maka manajemen yang dikembangkan lebih mengarah pada manajemen berbasis sekolah/madrasah (school based management) atau school based quality improvement management (manajemen peningkatan mutu berbasis sekolah/madrasah), yakni model manajemen yang memberikan otonomi lebih besar kepada sekolah/madrasah dan mendorong pengambilan keputusan partisipatif yang melibatkan secara langsung semua warga Sekolah/madrasah (guru, siswa, kepala sekolah, karyawan, orangtua siswa, dan masyarakat) atau stakeholders untuk meningkatkan mutu sekolah/madrasah.

Di antara otonomi yang lebih besar diberikan kepada sekolah/madrasah adalah menyangkut pengembangan kurikulum, yang kemudian disebut sebagai KTSP (Kurikulum Tingkat Satuan Pendidikan), yakni kurikulum operasional yang disusun oleh dan dilaksanakan di masing-masing satuan pendidikan (sekolah/madrasah). Sedangkan pemerintah pusat hanya memberi rambu-rambu yang perlu dirujuk dalam pengembangan kurikulum, yaitu: (1) Peraturan Pemerintah No.19 Tahun 2005 tentang Standar Nasional Pendidikan; (2) Peraturan Menteri Pendidikan Nasional Nomor 22 Tahun 2006 tentang Standar Isi (SI) untuk Satuan Pendidikan Dasar dan Menengah; (3) Peraturan Menteri Pendidikan Nasional Nomor 23 Tahun 2006 tentang Standar Kompetensi Lulusan (SKL) untuk Satuan Pendidikan Dasar dan Menengah; (4) Peraturan Menteri Pendidikan Nasional Nomor 24 tahun 2006 tentang Pelaksanaan dari kedua Peraturan Menteri Pendidikan Nasional tersebut; dan (5) panduan dari BSNP (Badan Standar Nasional Pendidikan). Panduan ini terdiri atas dua bagian, yaitu: pertama, Panduan Umum yang memuat ketentuan umum pengembangan kurikulum yang dapat diterapkan pada satuan pendidikan dengan mengacu pada Standar Kompetensi dan Kompetensi Dasar yang terdapat dalam SI dan SKL. Termasuk dalam ketentuan umum adalah penjabaran amanat dalam UU 20/2003 dan ketentuan PP 19/2005 serta prinsip dan langkah yang harus diacu dalam pengembangan KTSP. Kedua, model KTSP sebagai salah satu contoh hasil akhir pengembangan KTSP dengan mengacu pada SI dan SKL dengan berpedoman pada Panduan Umum yang dikembangkan BSNP. 


\section{B. Hakikat KTSP}

APA kurikulum yang pernah berlaku selama ini adalah Kurikulum 1968, Kurikulum 1975, Kurikulum 1984, Kurikulum 1994, Kurikulum 2004, dan mulai tahun ajaran 2006/2007 diberlakukan Kurikulum Tingkat Satuan Pendidikan (KTSP). Kebijakan ini berdasarkan Peraturan Menteri Pendidikan Nasional No. 23/2006 tentang Standar Kompetensi Lulusan untuk Satuan Pendidikan Dasar dan Menengah, dan Peraturan Menteri No. 22/2006 tentang Standar Isi untuk Satuan Pendidikan Dasar dan Menengah. Pada tahun 2010 seluruh sekolah harus sudah melaksanakan KTSP. Pelaksananan KTSP secara penuh diharapkan mulai tahun ajaran 2007.

Permendiknas KTSP ditandatangani pada 23 Mei 2006 dan berlaku bagi sekolah standar nasional maupun sekolah nasional berstandar internasional. Perlu ditegaskan bahwasanya standar pendidikan tidak sama dengan kurikulum. Standar nasional itu meliputi delapan hal, yaitu standar isi, standar proses, standar kompetensi lulusan, standar pendidik dan tenaga kependidikan, standar sarana dan prasarana, standar pengelolaan, standar pembiayaan, dan standar penilaian pendidikan. Kini masing-masing sekolah bisa membuat silabus, kurikulum, dan indikatorindikatornya sendiri, bahkan kepala dinas tidak boleh ikut campur dalam pengembangan KTSP sekolah.

Beberapa ciri terpenting dari KTSP adalah sebagai berikut :

1. KTSP menganut prinsip fleksibilitas. Setiap sekolah diberi kebebasan menambah empat jam pelajaran tambahan per minggu, yang bisa diisi dengan a pa saja baik yang wajib atau muatan lokal. Namun fleksibilitas ini mesti diimbangi dengan potensi sekolah masing-masing serta pemenuhan standar isi seperti digariskan Badan Standardisasi Nasional Pendidikan (BSNP). Standar adalah kualitas minimum yang mesti dicapai. Sementara itu, potensi adalah tersedianya SDM dan (pra)sarana yang memadai untuk menyelenggarakan pelajaran tambahan itu.

2. KTSP membutuhkan pemahaman dan keinginan sekolah untuk mengubah kebiasaan lama yakni kebergantungan pada birokrat. Peluang bagi sekolah untuk mengurus sendiri tidak hanya untuk manajemen sekolah, tetapi juga rutinitas akademis. Ini perlu waktu lama, karena selama ini sekolah terbiasa diatur oleh pemerintah. KTSP dikembangkan melalui beberapa hal, antara lain sesuai dengan satuan pendidikan, potensi daerah, kondisi sosial budaya masyarakat setempat, dan peserta didik.

3. Guru kreatif dan siswa aktif. Kurikulum 1994 menghendaki guru lebih kreatif, namun aktivitas guru sebatas mengajarkan apa yang sudah ditetapkan dalam kurikulum. Sementara dalam Kurikulum 2004 atau 
Kurikulum Berbasis Kompetensi (KBK), siswa dituntut lebih kreatif. Guru harus bisa "memaksa" siswa untuk memberi feedback dalam setiap pembelajaran. KTSP menggabungkan keduanya. Wajar jika mereka yang belum sempat melaksanakan KBK mendapat kesulitan dalam melaksanakan KTSP.

4. KTSP dikembangkan dengan menganut prinsip diversifikasi. Artinya, dalam kurikulum ini standar isi dan standar kompetensi lulusan yang dibuat BSNP itu dijabarkan dengan memasukkan muatan lokal, yakni lokal provinsi, lokal kabupaten/kota, dan lokal sekolah. Dengan demikian, sekolah akan berperan sebagai makelar kearifan lokal. Kegagalan kurikulum selama ini antara lain karena penyeragaman dari Sabang sampai Merauke, padahal masing-masing daerah berbeda potensinya, sehingga kurikulum nasional tidak operasional. Dengan kata lain, melalui KTSP diharapkan adanya keseimbangan antara kepentingan nasional dan kepentingan daerah.

5. KTSP sejalan dengan konsep desentralisasi pendidikan dan manajemen berbasis sekolah (school-based management). Komite sekolah kini harus 'turun gunung' bersama guru dalam mengembangkan kurikulum. Selama ini guru patuh pada petunjuk teknis dan petunjuk pelaksanaan yang disiapkan oleh birokrat Depdiknas. Sekolah dapat bermitra dengan berbagai pemangku peran (stakeholders) pendidikan, seperti industri, kerajinan, pariwisata, petani, nelayan, dan organisasi atau profesi lainnya. Para pemangku peran ini lazimnya lebih merasakan tantangan dunia sekitar yang memerlukan respon kurikuler. Keenam, KTSP tanggap terhadap perkembangan iptek dan seni. Inilah tantangan abad sekarang ini. Tanpa antisipasi cerdas terhadap perkara ini, kurikulum menjadi lunglai mengahadapi teknologi yang serba canggih ini. Walhasil, KTSP berpusat pada potensi, perkembangan, kebutuhan dan kepentingan peserta didik dan lingkungan, relevan dengan kebutuhan dan kehidupan, menyeluruh dan berkesinambungan, dan mestinya sejalan dengan prinsip belajar sepanjang hayat.

6. KTSP beragam dan terpadu. Walaupun sekolah diberi otonomi dalam pengembangannya, ujung-ujungnya ada ujian nasional (UN) juga. Seyogyanya tidak ada persoalan bagi sekolah karena yang diujikan adalah kompetensi dasar. Dalam semangat desentralisasi pendidikan, UN penting demi pemetaan kemampuan, bukan penentu kelulusan siswa. Biarkan sekolah menentukan kriteria kelulusan masing-masing, yakni dengan menggabungkan hasil UN dengan ujian sekolah masingmasing.

Perlu ditegaskan bahwa ada sejumlah fungsi UN, antara lain: (1) diagnosis, yakni untuk mengetahui 'penyakit' yang diderita anak didik untuk menentukan resep yang paling mujarab, (2) diferensiasi, yakni membeda-bedakan kelompok siswa demi penentuan kebijakan yang layak 
ditempuh, dan (3) uji kompetensi, yakni untuk mengetahui sejauh mana materi ajar dikuasai siswa. Fungsi pertama dan kedua selama ini belum betul-betul dilaksanakan dalam penyelenggaraan UN, sehingga selama ini belum jelas langkah korektif pemerintah sebagai respons terhadap hasil UN yang sangat beragam dari kota ke kota, bahkan dari sekolah ke sekolah.

\section{Tafsir Konstruktif Atas KTSP}

Niat pemerintah lewat BSNP memang luhur dan cerdas, namun berdasarkan kenyataan di lapangan, tidaklah mudah untuk memberdayakan para guru lewat KTSP ini. Ada anggapan bahwa apa pun kurikulumnya, selama guru, sekolah, dan pengembang kurikulumnya berpikiran tradisional, kurikulum itu tidak akan berdampak besar. Pengembang kurikulum menggonggong, guru-guru berlalu dengan kulturnya.

Aliran konstruktif menawarkan solusi untuk menyulap suasana belajar secara 'berani' dan mendobrak kejumudan kurikulum lewat tujuh ayat pendidikan sebagai berikut. Pertama, kurikulum disajikan secara utuh, yakni menekankan konsep besar, lalu diikuti konsep-konsep kecil. Artinya, guru berpegang pada tujuan instruksional umum atau TIU, dan tidak terjebak oleh hal-hal kecil, atau keterampilan-keterampilan dasar, atau tujuan instruksional khusus atau TIK. Dalam konteks KTSP, pemahaman guru akan standar kompetensi dan standar isi adalah sebuah niscaya.

Kedua, kegiatan kurikuler mengandalkan sumber-sumber data primer dan juga materi-materi buatan yang bermakna. Alam sekitar adalah data-data primer yang memiliki potensi untuk dibermaknakan. Dengan begitu, buku teks tidak lagi menjadi sumber utama sebagimana terbiasa pada kurikulum tradisional. Jadi wajar, jika KTSP tidak mesyaratkan adanya buku teks baru. Singkatnya, untuk KTSP, bukunya yang ada saja.

Ketiga, siswa diperlakukan sebagai 'pemikir' muda yang belajar merumuskan teorinya sendiri ihwal dunia (baca: materi ajar). Keberanian siswa untuk bertanya dan berdebat adalah indikator keberhasilan belajar. Ini berbeda dengan kelas tradisional yang cenderung menempatkan siswa sebagai 'botol kosong' untuk diisi informasi oleh guru.

Keempat, guru mengajar secara interaktif, yakni antara lain dengan kepandaian menerjemahkan lingkungan sekitar sehingga dapat dipahami siswa. Ini berbeda dari guru tradisional yang cenderung berlagak didaktik dalam menyebarkan informasi kepada siswa. Kebiasaan guru untuk mengejar target kurikuler sesuai dengan GBPP jelas tidak sejalan dengan prinsip konstruktif, sebab sebuah informasi belum tentu materi ajar yang bermakna (meaningful) dan terajarkan (teachable). 
Kelima, guru mencari tahu sudut pandang siswa untuk memahami kadar pengetahuan siswa saat ini untuk dijadikan pijakan bagi pelajaran yang akan datang. Ini berbeda dari kelas tradisional, di mana guru mencari jawaban yang benar untuk memvalidasi pembelajaran siswa. Pembelajaran konstruktivis membangun ketersambungan antara pelajaran sebelumnya dengan pelajaran selanjutnya. Dan ini hanya mungkin jika guru mengetahui sudut pandang siswa.

Keenam, siswa bekerja dalam kelompok. Ini berbeda dari kelas-kelas tradisional di mana siswa belajar secara mandiri. Justru dalam kelompoklah mereka bersosialisasi dan berkolaborasi, sehingga secara kolektif memperoleh pencerahan lewat social reconstructivism. Bila siswa bekerja dalam kelompok-kelompok kecil, guru dan pengembang kurikulum pun berkolaborasi dengan para pemangku peran dalam merumuskan KTSP. Jadi, siswa, guru, bahkan manajemen sekolah mengamalkan ajaran social reconstructivism.

Ketujuh, penilaian pembelajaran siswa dilakukan secara terintegrasi dalam pengajaran dan dilakukan lewat observasi guru terhadap proses belajar siswa dalam kelompoknya dan dengan mencermati portofolio siswa. Mekanisme ini berbeda dengan pendidikan tradisional yang memisahkan penilaian dari pembelajaran, dan terlembaga secara formal lewat tes. Dengan demikian, keberadaan UN sebagai satu-satunya penentu kelulusan siswa memang tidak relevan dengan semangat konstruktif..

\section{Model KTSP yang Dikembangkan di Sekolah/Madrasah}

KTSP yang disusun oleh dan dilaksanakan oleh sekolah/Madrasah berisi tentang hal-hal berikut:

Pertama, profil sekolah/madrasah, yang meliputi: tujuan satuan pendididkan dasar atau menengah; visi \& misi sekolah/madrasah; dan tujuan sekolah/madrasah itu sendiri. Rumusan tujuan pendidikan dasar atau menengah dapat mengacu pada Peraturan Pemerintah no. 19 tahun 2005 tentang Standar Nasional Pendidikan pada Bab V (Standar Kompetensi Lulusan) pasal 26, dan juga tertuang dalam buku panduan penyusunan KTSP dari BSNP.

Visi sekolah/madrasah menunjukkan gambaran sekolah/madrasah di masa yang akan datang (jangka panjang) yang diinginkan. Rumusan visi menggunakan kalimat keadaan dan perlu dijabarkan ke dalam indikatorindikatornya, sehingga jelas apa yang dicita-citakan. Rumusan visi yang baik setidak-tidaknya memberikan isyarat:

1. Berorientasi ke masa depan, untukjangka waktu yang lama

2. Menunjukkan keyakinan masa depan yang jauh lebih baik, sesuai dengan norma dan harapan masyarakat.

3. Mencerminkan standar keunggulan dan cita-cita yang ingin dicapai. 
4. Mencerminkan dorongan yang kuat akan tumbuhnya inspirasi, semangat dan komitmen warga.

5. Mampu menjadi dasar dan mendorong terjadinya perubahan dan pengembangan Madrasah ke arah yang lebih baik.

6. Menjadi dasar perumusan misi dan tujuan sekolah/madrasah.

Misi merupakan tindakan/upaya untuk mewujudkan visi sekolah/madrasah yang telah ditetapkan tersebut. Misi merupakan penjabaran visi dalam bentuk rumusan tugas, kewajiban, dan rancangan tindakan yang dijadikan arahan untuk mewujudkan visi dengan berbagai indikatornya. Rumusannya selalu dalam bentuk kalimat yang menunjukkan "tindakan", bukan kalimat yang menunjukkan "keadaan" sebagaimana pada rumusan visi.

Bertolak dari visi dan misi, selanjutnya perlu dirumuskan tujuan sekolah/ madrasah. Visi dan misi terkait dengan jangka waktu yang sangat panjang, sedangkan tujuan sekolah/madrasah dikaitkan dengan jangka waktu menengah. Sebaiknya tujuan itu dikaitkan dengan siklus program sekolah/madrasah, misalnya untuk jangka 3 tahunan, yaitu satu siklus pendidikan di SMP/MTs atau SMA/MA/SMK/MAK. Jika itu dianggap terlalu pendek dapat juga untuk 2 siklus program yang berarti 6 tahun. Tujuan yang ingin dicapai dalam jangka waktu 3 tahun dapat berwujud sebagian dari visi (tidak seluruhnya)

Kedua, standar kompetensi, yang setidak-tidaknya berisi tentang: (1) Standar Kompetensi Lulusan sekolah/madrasah; (2) Standar Kompetensi Kelompok Mata Pelajaran; (3) Standar Kompetensi Lulusan Mata Pelajaran; (4) Standar Kompetensi dan Kompetensi Dasar Mata Pelajaran; dan (5) Diagram Pencapaian Kompetensi Lulusan sekolah/madrasah.

Standar kompetensi lulusan (SKL) sekolah/madrasah diadopsi dari Peraturan Menteri Pendidikan Nasional Nomor 23 tahun 2006 tentang Standar Kompetensi Lulusan. SKL ini dipandang sudah cukup ideal, sehingga masing-masing sekolah/madrasah cukup mengacu pada Permendiknas tersebut. Demikian pula standar kompetensi lulusan kelompok mata pelajaran (SKL-KMP) cukup mengacu pada Peraturan Menteri Pendidikan Nasional Nomor 23 tahun 2006 tentang Standar Kompetensi Lulusan.

Adapun standar kompetensi lulusan mata pelajaran (SKL-MP) serta standar kompetensi dan kompetensi dasar (standar isi) mata pelajaran mengacu pada Peraturan Menteri Pendidikan Nasional Nomor 23 tahun 2006 tentang Standar Kompetensi Lulusan dan Nomor 22/2006 tentang Standar Isi. Di samping itu, untuk madrasah (Depag) perlu memperhatikan Surat Edaran Dirjen Pendidikan Islam Nomor: DJ.II.1/PP.00/ED/ 681/2006 tanggal 1 Agustus 2006, tentang pelaksanaan standar isi, bahwa 
Madrasah dapat mengembangkan kurikulum dengan standar yang lebih tinggi dengan melakukan inovasi dan akselerasi. Atas dasar itulah, maka madrasah dapat mengembangkan standar tersebut baik pada standar kompetensi lulusan mata pelajaran (SKL-MP) maupun standar isi (SK \& KD) mata pelajaran sebagaimana tertuang dalam Peraturan Menteri Pendidikan Nasional Nomor 22 dan 23 tahun 2006 tersebut, apalagi pada mata pelajaran PAI dan Bahasa Arab yang merupakan ciri khas dari Madrasah.

Sedangkan diagram pencapaian kompetensi lulusan sekolah/madrasah, digunakan untuk memberikan orientasi secara cepat kepada pembaca dan pengguna kurikulum berkaitan dengan posisi SK dan SK (standar isi), SKL-MP, SK-KMP sampai dengan SKL. Selain itu diagram juga digunakan untuk memetakan posisi muatan mata pelajaran sebagaimana dipersyaratkan dalam PP 19 tahun 2005 tentang Standar Nasional Pendidikan pasal 7. Pembuatan diagram pencapaian kompetensi lulusan akan menjadi lebih mudah jika setiap SK dan KD sebagai kompetensi terkecil dalam KTSP dilakukan peng-kode-an, serta pemberian garis dan warna yang berbeda dalam setiap kelompok Mata Pelajaran.

Ketiga, struktur kurikulum \& pengaturan beban belajar, yang dalam hal ini merujuk pada Permen Diknas no. 22 tahun 2006. Bagi Madrasah, juga perlu memperhatikan Surat Edaran Dirjen Pendidikan Islam Nomor: DJ.II.1/PP.00/ED/681/ 2006 tanggal 1 Agustus 2006, tentang pelaksanaan standar isi, yang di dalamnya juga ditetapkan struktur kurikulum pada masing-masing jenjang Madrasah (MI, MTs dan MA).

Misalnya pada MTs, di dalam Permendiknas tersebut dijelaskan bahwa struktur kurikulum SMP/MTs meliputi substansi pembelajaran yang ditempuh dalam satu jenjang pendidikan selama tiga tahun mulai Kelas VII sampai dengan Kelas IX. Struktur kurikulum MTs disusun berdasarkan standar kompetensi lulusan dan standar kompetensi mata pelajaran dengan ketentuan sebagai berikut.

1. Kurikulum SMP memuat 10 mata pelajaran, muatan lokal, dan pengembangan diri, sedangkan kurikulum MTs (berdasarkan Suat Edaran Dirjen Pendidikan Islam tersebut) memuat 11 mata pelajaran ditambah mata pelajaran Bahasa Arab.

2. Muatan lokal merupakan kegiatan kurikuler untuk mengembangkan kompetensi yang disesuaikan dengan ciri khas dan potensi daerah, termasuk keunggulan daerah, yang materinya tidak dapat dikelompokkan ke dalam mata pelajaran yang ada. Substansi muatan lokal ditentukan oleh satuan pendidikan.

3. Pengembangan diri bukan merupakan mata pelajaran yang harus diasuh oleh guru. Pengembangan diri bertujuan memberikan 
kesempatan kepada peserta didik untuk mengembangkan dan mengekspresikan diri sesuai dengan kebutuhan, bakat, dan minat setiap peserta didik sesuai dengan kondisi MTs. Kegiatan pengembangan diri difasilitasi dan atau dibimbing oleh konselor, guru, atau tenaga kependidikan yang dapat dilakukan dalam bentuk kegiatan ekstrakurikuler. Kegiatan pengembangan diri dilakukan melalui kegiatan pelayanan konseling yang berkenaan dengan masalah diri pribadi dan kehidupan sosial, belajar, dan pengembangan karir peserta didik.

4. Substansi mata pelajaran IPA dan IPS pada MTs merupakan "IPA Terpadu" dan "IPS Terpadu".

5. Jam pembelajaran untuk setiap mata pelajaran dialokasikan sebagaimana tertera dalam struktur kurikulum. Satuan pendidikan dimungkinkan menambah jam pembelajaran per minggu secara keseluruhan. Sehubungan dengan ini, MTs misalnya menambah 2 jam pembelajaran untuk Pendidikan Agama Islam dan 2 jam pembelajaran untuk Bahasa Arab.

6. Alokasi waktu satu jam pembelajaran adalah 40 menit.

7. Minggu efektif dalam satu tahun pelajaran (dua semester) adalah 34-38 minggu.

Sebagai contoh misalnya, struktur kurikulum MTs disajikan pada Tabel berikut:

\begin{tabular}{|l|c|c|c|}
\hline \multicolumn{2}{|c|}{ KOMPONEN } & \multicolumn{3}{|c|}{ KELAS \& } \\
\cline { 3 - 4 } & VLOKASI WAKTU \\
\cline { 2 - 4 } A. MATA PELAJARAN & & & \\
1. Pendidikan Agama Islam & 4 & 4 & 4 \\
2. Pendidikan Kewarganegaraan & 2 & 2 & 2 \\
3. Bahasa Indonesia & 4 & 4 & 4 \\
4. Bahasa Arab & 2 & 2 & 2 \\
5. Bahasa Inggris & 4 & 4 & 4 \\
6. Matematika & 4 & 4 & 4 \\
7. Ilmu Pengetahuan Alam & 4 & 4 & 4 \\
8. Ilmu Pengetahuan Sosial & 4 & 4 & 4 \\
9. Seni Budaya & 2 & 2 & 2 \\
10. Pendidikan Jasmani, Olah Raga dan & 2 & 2 & 2 \\
Kesehatan & 2 & 2 & 2 \\
11. Keterampilan/Teknologi Informasi dan & & & \\
Komunikasi & & & \\
\hline B. MUATAN LOKAL & 2 & 2 & 2 \\
\hline C. PENGEMBANGAN DIRI & $2 *)$ & $\left.2^{*}\right)$ & $\left.2^{*}\right)$ \\
\hline
\end{tabular}




\begin{tabular}{|l|l|l|l|}
\hline JUMLAH & 36 & 36 & 36 \\
\hline
\end{tabular}

1. PAI terdiri atas: Qur'an \& Hadits, Aqidah \& Akhlak, Fiqih, SKI

2. *) = Ekuivalen 2 jam pembelajaran

Keempat, kegiatan pengembangan diri, yang bertujuan mengembangkan potensi peserta didik secara optmal, yaitu menjadi manusia yang mampu menata diri dan menjawab berbagai tantangan baik dari dirinya sendiri maupun dari lingkungannya secara adaptif dan konstruktif baik di lingkungan keluarga maupun masyarakat. Pengembangan diri di sekolah/madrasah bersifat pilihan, dalam arti setiap siswa wajib mengikuti kegiatan pengembangan diri sebanyak-banyaknya 2 (dua) kegiatan pengembangan diri, tidak termasuk dalam pelayanan Bimbingan dan Konseling yang merupakan program pengembangan diri wajib.

Bentuk-bentuk kegiatan pengembangan diri adalah sebagai berikut:

1. Pelayanan Konseling: Hal ini akan dilakukan oleh BP dalam bentuk pelayanan berupa: (1) masalah kesulitan belajar peserta didik; (2) pengembangan karier peserta didik; (3) pemilihan jenjang pendidikan yang lebih tinggi; (4) masalah dalam kehidupan sosial peserta didik

2. Kelompok Ilmiah Remaja (KIR), yang bertujuan untuk: (1) melatih peserta didik berfikir kritis dan ilmiah; (2) melatih peserta didik terampil dalam menulis karya ilmiah; (3) melatih peserta didik mengkomunikasikan hasil temuannya kepada pihak lain; (4) malatih peserta didik melakukan penelitian ilmiah.

3. Palang Merah Remaja, yang bertujuan untuk: (1) melatih peserta didik untuk mampu menanggulangi dan menolong dalam setiap kecelakaan yang ada di sekitar; (2) mengembangkan jiwa sosial dan peduli terhadap orang lain; (3) membiasakan hidup sehat.

4. Pramuka, yang bertujuan: (1) sebagai wahana bagi peserta didik untuk berlatih berorganisasi; (2) melatih peserta didik untuk terampil dan mandiri.

5. Seni Bela Diri, yang bertujuan untuk: (1) menumbuhkembangkan sifat percaya diri pada anak; (2) memberikan bekal cinta perdamaian dan menghindari adanya penganiayaan; (3) membiasakan hidup sehat.

6. Seni Baca Al-Qur'an, yang bertujuan untuk: (1) menghargai dan menghormati kitab sucinya; (2) menumbuhkembangkan sifat cinta terhadap agama khusuanya pada kitab Suci Al-Qur'an; (3) melestarikan budaya islami.

7. Seni Musik (Qosidah), yang bertujuan untuk: (1) melestarikan budaya Islam; (2) memberikan bekal kecakapan hidup berupa seni qosidah; (3) menumbuh-kembangkan sifat cinta terhadap budaya Islam. 
8. Drum Band, yang bertujuan untuk: (1) menumbuhkan sifat cinta tanah air; (2) menumbuhkan sifat patriot pada peserta didik; (3) melestarikan budaya modern.

9. Pecinta Alam, yang bertujuan untuk: (1) menumbuhkan cinta tanah air; (2) memupuk jiwa cinta lingkungan; (3) menumbuhkan sifat mandiri.

10. Bimbingan Baca Kitab, yang bertujuan untuk: (1) memperkenalkan peserta didik tentang cara membaca dan memahami kitab; (2) menggali pengetahuan agama melalui sumber utama.

11. Jurnalistik, yang bertujuan untuk: (1) melatih peserta didik di bidang komunikasi.; (2) melatih peserta didik gemar membaca dan menulis.

12. Remaja Masjid, yang bertujuan untuk: (1) memakmurkan masjid; (2) mengadakan kajian dan pengembangan keagaman.

13. Latihan Kepemimpinan Dasar, yang bertujuan untuk: (1) mempersiapkan peserta didik untuk menjadi pemimpin yang handal; (2) melatih siswa bersikap demokratis; (3) melatih peserta didik untuk mengambil keputusan cepat dan tepat.

14. Olimpiade Training Center, yang bertujuan untuk: (1) mempersiapkan peserta didik untuk menjadi tutor sebaya di kelasnya masing-masing; (2) malatih memecahkan masalah yang berat; (3) mempersiapkan siswa untuk mengikuti olimpiade yang diadakan pemerintah atau perguruan tinggi.

15. Pendidikan Kesehatan Sekolah (PKS), yang bertujuan untuk: (1) mempersiapkan peserta didik untuk peduli terhadap kesehatan sekolah dan orang lain; (2) menjadi garda terdepan terhadap kedisiplinan anak.

16. Olah raga, yang bertujuan untuk: (1) mengembangkan bakat peserta didik di bidang olah raga; (2) membiasakan pola hidup sehat jasmani dan rohani.

Kelima, pendidikan kecakapan hidup (life skill), yakni kecakapan yang dimiliki seseorang untuk berani menghadapi problema hidup dan kehidupan dengan wajar tanpa merasa tertekan, kemudian secara proaktif dan kreatif mencari serta menemukan solusi sehingga mampu mengatasinya. Life skill ini dapat dikelompokkan ke dalam beberapa macam, yaitu:

a. Personal skill atau self awareness, yang mencakup: (1) penghayatan diri sebagai makhluk Tuhan (yang harus mengabdi kepadaNya dan menjadi khalifahNya di muka bumi), anggota masyarakat dan warga negara; (2) menyadari kelebihan dan kekurangannya serta mensyukuri segala nikmat yang diberikan kepadanya, sekaligus menjadikannya sebagai modal dalam meningkatkan dirinya sebagai individu yang bermanfaat bagi diri sendiri dan lingkungannya. 
b. Thinking skill, yang mencakup: (1) information searching skill atau kecakapan menggali dan menemukan informasi; (2) information processing and decision making skill atau kecakapan mengolah informasi dan mengambil keputusan; (3) creative problem solving skill atau kecakapan memecahkan masalah secara kreatif.

c. Social skill, yang mencakup: (1) kecakapan komunikasi dengan empati (communication skill); dan (2) kecakapan bekerjasama (collaboration skill).

d. Academic skill, atau kemampuan berfikir ilmiah (scientific method), yang mencakup antara lain: (1) identifikasi variable; (2) merumuskan hipotesis; dan (3) melaksanakan penelitian.

e. Vocational skill (kecakapan vokasional) atau ketrampilan kejuruan, yakni ketrampilan yang dikaitkan dengan pekerjaan tertentu yang terdapat di lingkungan atau masyarakatnya.

Di dalam kehidupan nyata sehari-hari, kelima kecakapan hidup tersebut tidak berfungsi secara terpisah-pisah, atau tidak terpisah secara eksklusif, tetapi justeru merupakan kesatuan yang terjadi pada tindakan individu, yang melibatkan aspek fisik, mental, emosional dan intelektual. Derajat kualitas tindakan individu dalam banyak hal dipengaruhi oleh kualitas kematangan berbagai aspek pendukung tersebut. Dalam pelaksanaannya pendidikan kecakapan hidup tersebut dapat dilaksanakan dengan dua cara, yaitu (1) diinternalisasikan dalam setiap mata pelajaran melalui strategi pembelajaran yang dilaksanakan oleh guru dalam PBM; dan (2) melalui mata pelajaran khusus, utamanya untuk kecakapan hidup vokasional.

Keenam, muatan local yang dimaksudkan untuk mengembangkan potensi daerah sebagai bagian dari upaya peningkatan mutu pendidikan di madrasah, serta mengembangkan potensi sekolah/madrasah sehingga memiliki keunggulan yang kompetitif. Muatan lokal bisa berbentuk keterampilan bahasa, baik bahasa daerah maupun bahasa asing, keterampilan dalam bidang Teknologi Informasi, atau bentuk keterampilan tepat guna yang lain. Muatan lokal disajikan dalam bentuk mata pelajaran, sehingga harus memiliki kompetensi mata pelajaran, standar kompetensi dan kompetensi dasar.

Ketujuh, penetapan ketuntasan belajar, sistem penilaian, pindah sekolah dan kelulusan. Dalam penetapan ketuntasan belajar, Madrasah mendasarkan pada peraturan yang berlaku dan kondisi nyata yang ada di madrasah. Peraturan yang berlaku meliputi peraturan yang dikeluarkan oleh pemerintah pusat yang berlaku secara nasional, peraturan yang dikeluarkan oleh daerah dan peraturan yang dikeluarkan oleh lembaga. Ketiga peraturan tersebut harus bersifat saling memperkuat. Kondisi nyata di madrasah dapat berpijak pada kualitas input siswa dan kondisi sumberdaya madrasah. Dengan mempertimbangkan kondisi tersebut, 
dalam setiap awal ajaran baru, guru (dengan melalui forum guru serumpun) dapat menetapkan standar ketuntasan belajar minimal. Standar ketuntasan belajar minimal tersebut harus diinformasikan kepada seluruh warga madrasah dan orang tua.

Madrasah dapat menetapkan batas/standar ketuntasan belajar minimal di bawah nilai ketuntasan belajar maksimum (100), dengan catatan madrasah harus merencanakan target dalam waktu tertentu untuk mencapai nilai ketuntasan belajar ideal. Nilai ketuntasan belajar minimum ditetapkan untuk setiap mata pelajaran oleh forum guru pada awal tahun pelajaran. Standar ketuntasan belajar minimal tersebut harus diinformasikan kepada seluduh warga sekolah dan orangtua siswa.

Penetapan nilai ketuntasan belajar minimum dilakukan melalui analisis ketuntasan minimum pada setiap KD. Setiap KD dimungkinkan adanya perbedaan nilai ketuntasan belajar minimal dan penetapannya harus memperhatikan hal-hal sebagai berikut:

Tingkat essensial (kepentingan) setiap KD terhadap SK yang harus dicapai oleh siswa pada setiap tahun pelajaran. KD yang sangat essensial misalnya, perlu dicapai oleh siswa dengan nilai ketuntasan $\geq$ 80, sedangkan KD yang sifatnya pendukung dapat dicapai oleh siswa sekurang-kurangnya 75.

> Tingkat Kompleksitas (kerumitan dan kesulitan) setiap KD yang harus dicapai oleh siswa

$>$ Tingkat kemampuan rata-rata siswa pada madrasah yang bersangkutan.

Kemampuan sumber daya pendukung dalam penyelenggaraan pembelajaran pada masing-masing madrasah.

Sistem Penilaian dilaksanakan pada setiap akhir tahun pelajaran, dengan ketentuan-ketentuan misalnya untuk di MTs: (1) siswa dinyatakan tidak naik ke kelas VIII atau ke kelas IX, apabila yang bersangkutan tidak mencapai ketuntasan belajar minimal, lebih dari 3 (tiga) mata pelaja ran; (2) siswa yang tidak naik kelas, diwajibkan mengulang yaitu mengikuti seluruh kegiatan pembelajaran pada tingkat kelas yang sama pada tahun pelajaran berikutnya.

Laporan Hasil Belajar Siswa disampaikan kepada siswa dan orang tua/wali siswa, setiap akhir semester. Ketuntasan Belajar siswa ditetapkan oleh musyawarah guru bidang studi berdasarkan acuan yang ditetapkan oleh madrasah masing-masing. Standar Ketuntasan Belajar Minimal (SKBM) siswa tesebut berbeda pada tiap mata pelajaran. Misalnya di MTs tertentu SKBM ditetapkan sebagai berikut:

\begin{tabular}{|l|l|l|l|}
\hline NO. & MATA PELAJARAN & SKBM & KETERANGAN \\
\hline
\end{tabular}




\begin{tabular}{|c|l|c|l|}
\hline 1 & Pend. Agama Islam & 75 & \\
\hline 2 & Pend. Kewarganegaraan & 75 & \\
\hline 3 & Bahasa Indonesia & 70 & \\
\hline 4 & Bahasa Arab & 65 & \\
\hline 5 & Bahasa Inggris & 65 & \\
\hline 6 & Matematika & 60 & \\
\hline 7 & Ilmu Pengetahuan Alam & 60 & \\
\hline 8 & Ilmu Pengetahuan Sosial & 70 & \\
\hline 9 & Seni Budaya & 75 & \\
\hline 10 & $\begin{array}{l}\text { Pendidikan Jasmani, Olah } \\
\text { Raga dan Kesehatan }\end{array}$ & 75 & \\
\hline 11 & $\begin{array}{l}\text { Keterampilan/Teknologi } \\
\text { Informasi dan Komunikasi }\end{array}$ & 75 & \\
\hline 12 & Dan seterusnya & & \\
\hline
\end{tabular}

Sehubungan dengan pindah sekolah, maka Madrasah harus memfasilitasi adanya siswa yang pindah sekolah: antar madrasah pelaksana Kurikulum 2004 atau antara madrasah pelaksana Kurikulum dengan sekolah pelaksana Kurikulum '94. Untuk pelaksanaan pindah madrasah lintas Provinsi/Kabupaten/Kota, dikoordinasikan dengan Dinas Pendidikan Provinsi/Mapndais Kanwil Depag dan Kabupaten/Kota setempat.

Madrasah dapat menentukan persyaratan pindah/mutasi siswa sesuai dengan prinsip manajemen berbasis madrasah, antara lain mencakup hal-hal sebagai berikut (1) menyesuaikan bentuk laporan hasil belajar siswa (LHBS) dari madrasah/sekolah asal sesuai dengan bentuk raport yang digunakan oleh madrasah/sekolah tujuan; (2) melakukan tes atau matrikulasi bagi siswa pindahan.

Sedangkan masalah kriteria kelulusan ujian nasional dan ujian madrasah dapat ditentukan misalnya: seorang siswa dinyatakan LULUS apabila memenuhi 2 (dua) aspek yaitu Aspek Akademik dan Aspek Non Akademik. Aspek Akademik, meliputi: (1) memiliki nilai rapor yang lengkap untuk kelas 1, 2, dan 3; (2) telah memiliki nilai ujian untuk seluruh mata pelajaran yang diujikan; (3) fidak terdapat nilai $\leq 4,5$ baik untuk ujian tulis maupun ujian praktek seluruh mata pelajaran yang diujikan dengan nilai rata-rata Ujian Nasional maupun Ujian Madrasah tidak boleh $\leq 5,00$. Sedangkan untuk aspek non Akademik, meliputi: (1) nilai rata-rata kepribadian (kelakuan, kerajinan dan kerapian) pada semester II kelas III minimal Baik; (2) kehadiran di Madrasah pada semester I dan II kelas III minimal 90\% dari jumlah hari efektif. Karena itu, seorang siswa dinyatakan TIDAK LULUS a pabila tidak memenuhi Aspek Akademik dan Aspek Non Akademik tersebut. 
Kedelapan, revisi dan pengembangan kurikulum. Untuk menjaga reliabilitas dan validitas kurikulum yang dipakai perlu adanya aturan tentang revisi dan atau perubahan serta pengembangan kurikulum secara terarah. Adapun aturan-aturan perubahan tersebut misalnya sebagai berikut: (1) kurikulum Tingkat Satuan Pendidikan ini bisa direvisi dan diubah apabila ada perubahan kebijakan pemerintah dalam kurikulum pndidikan dasar; (2) Kurikulum Tingkat Satuan Pendidikan ini hanya bisa direvisi dan diubah demi mempertimbangkan diktum a, pada rapat kerja madrasah; (3) Kurikulum Tingkat Satuan Pendidikan direvisi dan diubah dengan mempertimbangkan masukan dari tim penyusun KTSP yang dibentuk madrasah dengan melibatkan semua elemen yang dibutuhkan; (4) Kurikulum Tingkat Satuan Pendidikan ini bisa direvisi dan diubah apabila pelaku pendidikan yang ada dalam madrasah ingin merubah visi, misi dan tujuan pendirian madrasah; (5) perubahan tersebut hanya bisa dilakukan dengan rapat kerja madrasah; (6) apabila tidak ada perubahan Kurikulum pendidikan dasar secara nasional oleh pemerintah, maka Kurikulum Tingkat Satuan Pendidikan ini setidak-tidaknya direvisi dan diubah, serta dikaji pada setiap awal tahun pelajaran baru.

Adapun masalah pengembangan Kurikulum Tingkat Satuan Pendidikan dimaksudkan agar madrasah selalu mengikuti perkembangan teori pendidikan dan perkembangan zaman. Pada setiap guru mata pelajaran yang ada di madrasah, demi perkembangan Kurikulum Tingkat Satuan Pendidikan, diharuskan membuat perangkat pembelajaran secara terpadu pada setiap mata pelajaran yang menjadi tanggung jawabnya. Perubahan perangkat pembelajaran yang ada pada setiap mata pelajaran yang menjadi tanggung jawab setiap guru mata pelajaran setidak-tidaknya dikembangkan pada setiap semester. Perangkat pembelajaran yang ada, khususnya pengembangan silabus dan sistem penilaian harus selalu berkembang mengikuti teori-teori pembelajaran baru yang berkembang di dunia pendidikan. Sistem penilaian yang ada dalam perangkat pembelajaran harus selalu disesuaikan dengan ketuntasan belajar yang ada pada madrasah tersebut.

Kesembilan, kalender pendidikan. Hal-hal yang perlu diperhatikan adalah: (1) kalender Pendidikan adalah pengaturan waktu untuk kegiatan pembelajaran peserta didik selama satu tahun ajaran yang mencakup permulaan tahun pelajaran, minggu efektif belajar, waktu pembelajaran efektif dan hari libur; (2) permulaan tahun pelajaran adalah waktu dimulainya kegiatan pembelajaran pada awal tahun pelajaran; (3) minggu efektif belajar adalah jumlah minggu kegiatan pembelajaran untuk setiap tahun pelajaran; (4) waktu pembelajaran efektif adalah jumlah jam setiap minggu, meliputi jumlah jam untuk setiap mata pelajaran termasuk muatan lokal, ditambah dengan jumlah jam untuk kegiatan pengembangan diri; (5) waktu libur adalah waktu yang ditetapkan untuk tidak diadakan kegiatan pembelajaran. Waktu libur dapat berbentuk jeda tengah semester, 
jeda antar semester, libur akhir tahun pelajaran, hari libur keagamaan, hari libur umum, termasuk hari-hari besar nasional dan hari libur khusus.

Kesepuluh, lampiran silabus dari masing-masing mata pelajaran, yang disusun oleh guru atau kelompok guru mata pelajaran, dan akan dilaksanakan dalam pembelajaran sebagai actual curriculum.

\section{E. Penyusunan KTSP dan Waktu Implementasinya}

Siapa penyusun KTSP dan kapan KTSP itu harus disusun dan dilaksanakan? Tim penyusun KTSP pada SD, SMP, SMA dan SMK terdiri atas guru, konselor, dan kepala sekolah sebagai ketua merangkap anggota. Di dalam kegiatan tim penyusun melibatkan komite sekolah, dan nara sumber, serta pihak lain yang terkait. Supervisi dilakukan oleh dinas yang bertanggung jawab di bidang pendidikan tingkat kabupaten/kota untuk SD dan SMP dan tingkat provinsi untuk SMA dan SMK. Sedangkan Tim penyusun KTSP MI, MTs, MA dan MAK terdiri atas guru, konselor, dan kepala madrasah sebagai ketua merangkap anggota. Di dalam kegiatan tim penyusun melibatkan komite madrasah, dan nara sumber, serta pihak lain yang terkait. Supervisi dilakukan oleh departemen yang menangani urusan pemerintahan di bidang agama.

Penyusunan KTSP merupakan bagian dari kegiatan perencanaan sekolah/madrasah. Kegiatan ini dapat berbentuk rapat kerja dan/atau lokakarya sekolah/madrasah dan/atau kelompok sekolah/madrasah yang diselenggarakan dalam jangka waktu sebelum tahun pelajaran baru. Tahap kegiatan penyusunan KTSP secara garis besar meliputi: penyiapan dan penyusunan draf, reviu dan revisi, serta finalisasi, pemantapan dan penilaian. Langkah yang lebih rinci dari masing-masing kegiatan diatur dan diselenggarakan oleh tim penyusun.

Dokumen KTSP pada SD, SMP, SMA, dan SMK dinyatakan berlaku oleh kepala sekolah setelah mendapat pertimbangan dari komite sekolah dan diketahui oleh dinas tingkat kabupaten/kota yang bertanggung jawab di bidang pendidikan untuk SD dan SMP, dan tingkat propinsi untukSMA dan SMK. Sedngkan Dokumen KTSP pada MI, MTs, MA, dan MAK dinyatakan berlaku oleh kepala madrasah setelah mendapat pertimbangan dari komite madrasah dan diketahui oleh departemen yang menangani urusan pemerintahan di bidang agama.

Kapan sekolah/madrasah harus menerapkan KTSP tersebut? Di dalam Peraturan Menteri Pendidikan Nasional Nomor 24 tahun 2006 dinyatakan bahwa Satuan pendidikan dasar dan menengah: (1) dapat menerapkan Peraturan Menteri Pendidikan Nasional Nomor 22 Tahun 2006 tentang Standar Isi Untuk Satuan Pendidikan Dasar dan Menengah dan Peraturan Menteri Pendidikan Nasional Nomor 23 Tahun 2006 tentang Standar Kompetensi Lulusan Untuk Satuan Pendidikan Dasar dan Menengah mulai tahun ajaran 2006/2007; (2) harus mulai menerapkannya 
paling lambat tahun 2009/2010; (3) Bagi satuan pendidikan yang telah melaksanakan uji coba kurikulum 2004 secara menyeluruh dapat menerapkan untuk semua tingkatan kelasnya mulai tahun ajaran 2006/2007. Hal ini mengandung makna bahwa kurikulum 2004 tidak jauh berbeda dengan rambu-rambu KBK tahun 2006; (4) Satuan pendidikan dasar dan menengah yang belum melaksanakan uji coba kurikulum 2004, melaksanakan secara bertahap dalam waktu paling lama 3 tahun, dengan tahapan sebagai berikut:

a. Untuk sekolah dasar (SD), madrasah ibtidaiyah (MI), dan sekolah dasar luar biasa (SDLB):

- tahun I : kelas 1 dan 4;

- tahun II : kelas 1,2,4, dan 5;

- tahun III: kelas 1,2,3,4,5 dan 6.

b. Untuk sekolah menengah pertama (SMP), madrasah tsanawiyah (MTs), sekolah menengah atas (SMA), madrasah aliyah (MA), sekolah menengah kejuruan (SMK), madrasah aliyah kejuruan (MAK), sekolah menengah pertama luar biasa (SMPLB), dan sekolah menengah atas luar biasa (SMALB) :

- tahun I : kelas 1;

- tahun II : kelas 1 dan 2;

- tahun III : kelas 1,2, dan 3.

\section{F. Penutup}

Pengembangan KTSP merupakan suatu kegiatan yang tak pernah selesai, dalam arti ia harus dilakukan secara terus menerus dan berkelanjutan baik dalam aspek perencanaan, implementasi maupun evaluasinya. Hanya saja dalam tradisi kita biasanya ketika kita melakukan pengembangan kurikulum lebih banyak disibukkan dan/atau berhenti pada aspek curriculum plan (kurikulum sebagai dokumen), yang meliputi: (1) perumusan standar kompetensi lulusan; (2) penentuan serangkaian mata pelajaran serta bobot sksnya; (3) penyusunan silabus; dan (4) penyusunan program kegiatan (SAP). Sedangkan pada aspek actual curriculum atau kegiatan nyata biasanya terlupakan, seperti masalah proses pembelajaran, proses evaluasi (assessment) termasuk di dalamnya uji kompetensi, dan penciptaan suasana pembelajaran. Padahal, apa artinya KTSP sebagai dokumen jika tidak ditindaklanjuti dengan acual curriculum. Karena itu, dalam kegiatan pengembangan kurikulum ini perlu memperhatikan kedua-duanya.

\section{G. Daftar Rujukan}


Mulyasa, E, 2005, Kurikulum Berbasis Kompetensi (Konsep, Karakteristik, dan Implementasi), Yokyakarta: Rosda Karya.

Muhaimin, Prof. Dr, 2006, Kesiapan Sekolah/Madrasah Dalam Pengembangan KTSP, Gresik: Makalah pada acara seminar.

Muslikh, Mansur, 2007, Kurikulum Tingkat Satuan Pendidikan (KTSP), Jakarta: Bumi Aksara.

Sanjaya, Wina, M.Pd., 2008, Kurikulum dan Pembelajaran (Teori dan Praktik Pengembangan Kurikulum Tingkat Satuan Pendidikan), Jakarta: Bumi Aksara.

Tilaar, H.A.R, \& Nugroho, Riant, 2008, Kebijakan Pendidikan (Pengantar Untuk Memahami Kebijakan Pendidikan dan Kebijakan Pendidikan Sebagai Kebijakan Publik), Jakarta: Pustaka Pelajar

Mulyasa, E, 2008, Implementasi Kurikulum Tingkat Satuan Pendidikan (Kemandirian Guru dan Kepala Sekolah), Jakarta: Bumi Aksara.

Joko Susilo, Muhammad, 2008, Kurikulum Tingkat Satuan Pendidikan (KTSP), Yokyakarat:Pustaka Pelajar.

2008, Mewujudkan Pendidikan yang Mencerdaskan Kehidupan Bangsa, Makalah dalam diskusi Pendidikan diselenggarakan oleh BEM-UNY, Yokyakarta, 26 Februari 2008. 